\title{
The Different Effects of Supporting Activity Component in Increasing the Feel of Safety
}

\author{
Atoosa Izadifar1', Seyed-Abbas Yazdanfar2, \\ Seyed-Bagher Hosseini ${ }^{3}$, Saeid Norouzian-Maleki ${ }^{4}$
}

${ }^{1}$ M.A. in Architecture, ${ }^{2}$ Assistant Professor, ${ }^{3}$ Associate Professor, School of Architecture and Environmental Design, Iran University of Science and Technology, Iran

${ }^{4}$ Assistant Professor, Faculty of Architecture and Urban Design Engineering,

Shahid Rajaee Teacher Training University, Iran

atoosaizadifar@arch.iust.ac.ir_yazdanfar@iust.ac.ir_hosseini@iust.ac.ir_s_norouzian@iust.ac.ir_

\begin{abstract}
Fear of crimes has been led to restrictions on freedom residents and prevented them from participating in the public domain. One of the strategies to overcome the crime is (CPTED) which emphasizes on decreasing delinquencies by urban design and through modelling it's principles in public open spaces. A survey on the perception of the relationship between support of social activities and fear of crime among 60 residents in Omid Residential Complex was conducted. The results found that the usage location, providing usage in the abandoned spaces and usage combination, have the highest impact on the residents' place attachment, respectively.
\end{abstract}

Keywords: CPTED viewpoint; fear of crime; residential complex; social activity.

eISSN 2514-7528 @ 2018. The Authors. Published for AMER ABRA cE-Bs by e-International Publishing House, Ltd., UK. This is an open-access article under the CC BY-NC-ND license (http://creativecommons.org/licenses/bync-nd/4.0/). Peer-review under responsibility of AMER (Association of Malaysian Environment-Behaviour Researchers), ABRA (Association of Behavioural Researchers on Asians) and $c E-B s$ (Centre for EnvironmentBehaviour Studies), Faculty of Architecture, Planning \& Surveying, Universiti Teknologi MARA, Malaysia.

DOI: https://doi.org/10.21834/jabs.v5i21.119 


\subsection{Introduction}

Crime in residential Complex has been a social problem that has an improper influence on the life of thousands of residents every year (Abdul Mohit \& Elsawahli, 2010). Fear of crimes (FOC) has been led to restrictions on freedom of traffic of residents and prevented them from attending and participating in the public domain and the open spaces (Newman, 1972).

Nowadays in design processes of a residential Complex, it is better to pay attention to the possible potential of residential complex, buildings and open spaces in reducing or preventing crimes. Security issue has always considered as one of the human basic needs and one of the ways to support social capital. Many studies indicate that the physical environment can increase or decrease opportunities for crime (Newman, 1972). One of the strategies to overcome the crime by environmental design is (CPTED) that through modelling its principles and appropriate design of public open spaces can effectively reduce these problems (Jeffery, 1974, Crowe, 2000, Newman, 1972).

CPTED is one of the most effective ways to reduce FOC. Therefore, some researchers investigated the relationship between physical attributes and attitudes of CPTED and FOC (Sakip et al., 2012a). Safe city concept is one approach and as part of liveable city's theory focuses on the crime problem in urban areas (Anuar et al., 2012). In recent years, it is also suggested that community crime prevention has some effect to an activation of local communication and improvement of residents' sense of security (Shibata et al., 2010). Research have provided evidence that areas characterized by limited prospect, blocked escape and high concealment evoke fear and those physical environmental characteristics associated with higher levels of crime (Sakip et al., 2012b).

This study attempts to demonstrate the impacts of supporting the social activities of residents on the place attachment and socialization by focusing on the CPTED dimensions. The objectives of this study are to assessment some tangible effect of CPTED that can easily tackle crime with environmental design and provide an appropriate approach for reducing urban crimes in public open spaces and residential complex for improving quality of life and satisfaction.

\subsection{Literature Review}

Crime is an act punishable by law, as being forbidden by statute or injurious to the public welfare (Abdul Mohit \& Elsawahli, 2010). Crime and the fear of crime are serious threats to the stability, social climate of cities, sustainable and economic development, the quality of life and human rights (Karim \& Abdul Rashid, 2010). The urban environment is like a magnet pulling all types of human activities including the negative and illegal activities which have put a lot of stress on the urban community which developed into a type of fear known as fear of crime. Fear of crime, or its opposite, feelings of personal safety, is the dominant predictor of neighbourhood satisfaction (Karim \& Abdul Rashid, 2010). Fear of crime has become a serious social problem demanding scientific understanding and social reaction (Sakip et al., 2013). Increasing the public confidence on their safety is crucial (Soh, 2010). According to the national police agency, the number of crime prevention volunteer organizations has been increased by more than ten times (Shibata et al., 2011). 
In general, research shows that the fear of crime has influenced by five factors, which are the physical environment, social environment, victimization, crime-specific, and crime problems in the neighborhood (Abdullah et al., 2012).

Two Canadian researchers Wekerle and Whitzman (1995) expressed three factors to enhance safety and security in Urban Space:

1) Awareness of the environment, 2) Visibility by others, 3) Easy aid access if needed Petrella (2004) arises three main modalities in a category of crime prevention:

1) Law enforcement, 2) Identification at risk groups and Performance Social prevention proceedings and 3 ) planning and physical management

General knowledge and empirical evidence showed that crime occurs more in some environments which can easily evoke higher levels of fear than others (Cinar \& Cubukcu, 2013).

The need for security in urban areas formed the documentary theories like defensible spaces and CPTED (Pourjafar et al., 2008). Crime prevention theories have been developed by three schools of thoughts. The three schools of thoughts are as follows (Abdul Mohit \& Elsawahli, 2010):

Oscar Newman (defensible space) that includes that access to the area should be restricted to legal users. According to the Newman definition, Defensible space is a term for a series of space systems, including real and symbolic barriers, defined spheres of influence and the possibility of further care that together, make the media controllable for population. In this area, criminal activities occur less (Newman, 1996).

Jeffery's crime prevention through environmental design (CPTED) contains a mutual support to defensible space theory and takes it a step further by the manipulation of the physical environment to influence behavior to deter crime. The Crime Prevention through Environmental Design (CPTED) approach emphasizes on the elimination of opportunities for the occurrence of crime through planning and design (Jeffery, 1974; Clarke, 1997). Our surroundings are not the only areas where crimes occur, but the structure and space designing can lead to the prevention of criminal activity and improve the urban security (Wekerle and Whitzman, 1995).

Clarke's situational crime prevention takes both theories into consideration while including management and design interventions to reduce crime. The theory develops social and economic strategies to achieve a sustainable environment (Abdul Mohit \& Elsawahli, 2010).

\subsection{CPTED dimension}

CPTED is based on five main components: 1) territoriality, 2) surveillance, 3) access control, 4) maintenance and target hardening and, 5) support activity:

\subsubsection{Territoriality}

Territorial behaviour is an act of personalisation a place or object and communication that is owned by a person or group (Marzbali et al., 2012). Territoriality can be defined as a sense 
of ownership by legitimate users of space, thereby reducing opportunities for offending by discouraging illegitimate users (Sakip et al., 2012a).

\subsubsection{Surveillance}

If people feel that the others observe them, they will reduce the possibility of committing a crime. There are a variety types of surveillance including natural surveillance (residents' opportunities to see from windows), formal or organized surveillance and mechanical surveillance strategies (street lighting and cameras) (Cozens et al., 2008). In this regard, it seems that direct surveillance over urban areas has to be possible for citizens to prevent the creation of invisible or non-accessible places that can easily increase the probability of committing a crime (Pourjafar et al., 2008).

\subsubsection{Access control}

Access control reduces the crime by denying access to potential targets (Sakip et al., 2012a). In Site designing, paying attention to the location and accessibility of the inputs and outputs of the site is important to define the kind of transparency in the site (Pourjafar et al., 2008).

Maintenance and target hardening

Home maintenance may enable residents to keep up their home and express stronger, which is related to crime and other predictors of incivilities (Marzbali et al., 2012). Proper maintenance and management of urban furniture, signs and lighting can optimize the costs of urban areas in addition to reducing crimes (Cozens et al., 2001).

\subsubsection{Support activity}

Support activity can be defined as the use of design to encourage patterns of usage in public spaces (Sakip et al., 2012a). It is the programs or activities that involve the local community to create a secure and safe space (Sakip \& Abdullah, 2010). It increases the amount of human supervision in the environment and decrease criminals presence. This approach significantly includes components such as territoriality, access control and surveillance (Crowe, 2000).

Nevertheless, the measurement of all these components of CPTED in research is still very limited. The majority of previous research focused mainly on a single component of CPTED alone, for example, territoriality, surveillance, access control, maintenance and target hardening (Sakip et al., 2012b). Mohit et al. (2010) measured all five of the CPTED components in their research. Sakip \& Abdullah (2010) and Sakip et al. (2012a) conducted an evaluation of four CPTED components, namely, territoriality, surveillance, support activity and maintenance. Abdullah et al. (2012) undertook a research based on three CPTED components, namely, surveillance, maintenance and territoriality.

\subsection{Hypothesis}

Between these five proposed CPTED dimensions, the research focuses on supporting social activities on reducing crime and fear of crime in housing complexes were less likely than other parameters. In the environment design, we try to increase the participation of people and residents in the area to increase surveillance and informal social control. Encouraging 
people to perform certain activities in public spaces can prevent committing a crime. The presence of the recreational space or library can increase surveillance, place attachment and to him replaced, social interaction. So the kind of defined usage our definition about these usages, combination different usage, usage location and providing usage in the abandoned spaces can improve security and socialization.

This study attempts to demonstrate the impacts of supporting the social activities of residents on increasing security and socialization. We believe that increase of residents' attendance and their variety of activities will reduce criminal opportunities (Table 1).

Table 1: The main hypotheses of in this paper

\begin{tabular}{|c|c|c|}
\hline & & Hypothetic \\
\hline 1 & Type of usage & $\begin{array}{l}\text { The defined types of usage in a residential complex affect the sense of } \\
\text { security and socialization. Commercial usage increases the sense of } \\
\text { security and socialization more than the other usages. }\end{array}$ \\
\hline 2 & $\begin{array}{l}\text { Combining different } \\
\text { usages }\end{array}$ & $\begin{array}{l}\text { Some usages have a different effect on people when they use } \\
\text { independently in compare to place alongside the other usages. This issue } \\
\text { can be examined in two parts: local and ultra-local services. }\end{array}$ \\
\hline 3 & Place of usage & $\begin{array}{l}\text { In residential complexes, we can locate usages in the center, around or } \\
\text { between the buildings. The place of usages effect residents' usage, } \\
\text { socialization and sense of security. Service's usages such as library and } \\
\text { gym can increase the sense of security among residents. }\end{array}$ \\
\hline 4 & $\begin{array}{l}\text { Providing usage in the } \\
\text { abandoned spaces }\end{array}$ & $\begin{array}{l}\text { Unused spaces are the most talented spaces for occurring crime and a } \\
\text { sense of security and socialization is less than other spaces. The kind of } \\
\text { usage that can define in these spaces can be very efficiently to reach the } \\
\text { objective of this paper that is increasing the sense of security and } \\
\text { socialization. }\end{array}$ \\
\hline
\end{tabular}

\subsection{Methodology}

The research in the field of theoretical literature is an applied research in the area of field studies is a descriptive - survey method. The hypothesis has been examined through selecting the case study. The case study, Omid residential complex, is located in northeastern of Tehran. This complex is built in 1976. 1946 households and 9000 people live in this area. The main reasons for choosing this case study are as follows:

This complex has $76 \%$ open spaces, but they are not useful and these spaces are known as abandoned spaces or abandoned parks that socialization and sense of security is very low. Omid residential complex is a significant sample of complex that residents can find all kind of activity in it. So it is an independent complex with a different kind of usages in different places in combination with residential building.

Data have been collected through documental studies, observations and questionnaires. To obtain the environmental information, 60 questionnaires were distributed among residents of the district. The Likert scale was used to analyze the questionnaire data and obtain the mean of each variable to compare and evaluate them together. The data were analyzed using SPSS software. 


\subsection{Results and Discussion}

Table 2: Respondents' information (sex and educational)

\begin{tabular}{|c|c|c|c|c|c|c|c|c|}
\hline \multirow{2}{*}{$\begin{array}{c}\text { Respondents } \\
\text { information }\end{array}$} & \multicolumn{4}{|c|}{ Sex } & \multicolumn{6}{c|}{ Education } \\
\cline { 2 - 9 } & male & female & Total & $\begin{array}{c}\text { High } \\
\text { school }\end{array}$ & College & Bachelor & Master/ PhD & Total \\
\hline Frequency & 26 & 34 & 60 & 8 & 1 & 21 & 30 & 60 \\
\hline Percent & 43.3 & 56.7 & 100 & 13.3 & 1.7 & 35 & 50 & 100 \\
\hline
\end{tabular}

Table 3: Respondents' perception about the effect of combining different usage, location of usage and using abandoned spaces in socialization and the sense of security.

\begin{tabular}{llcccccc}
\hline \multirow{5}{*}{ Security } & $\begin{array}{c}\text { Strongly } \\
\text { agree }\end{array}$ & Agree & Disagree & $\begin{array}{c}\text { Strongly } \\
\text { disagree }\end{array}$ & Mean & $\begin{array}{c}\text { Std. } \\
\text { Deviation }\end{array}$ \\
\cline { 2 - 7 } & $\%$ & $\%$ & $\%$ & $\%$ & & \\
\hline \multirow{5}{*}{ Socialization } & $\begin{array}{l}\text { Combining } \\
\text { different } \\
\text { usages } \\
\text { Location of } \\
\text { usages } \\
\text { Use } \\
\text { abandoned }\end{array}$ & 20 & 61.7 & 18.3 & - & 3.83 & .960 \\
& $\begin{array}{l}\text { spaces } \\
\text { Combining } \\
\text { different } \\
\text { usages } \\
\text { Use } \\
\text { abandoned } \\
\text { spaces }\end{array}$ & 40 & 43.7 & - & - & 4.57 & .500 \\
\hline
\end{tabular}

Table 4: Respondents' perception about the effects of combining different usage, location of usage and using abandoned spaces in socialization and the sense of security level in their residential complex.

\begin{tabular}{llcccccc}
\hline \multirow{5}{*}{ Security } & $\begin{array}{c}\text { Very } \\
\text { much }\end{array}$ & Much & Low & $\begin{array}{l}\text { Very } \\
\text { low }\end{array}$ & Mean & $\begin{array}{c}\text { Std. } \\
\text { Deviation }\end{array}$ \\
\cline { 2 - 7 } & $\%$ & $\%$ & $\%$ & $\%$ & & \\
\hline \multirow{5}{*}{ Socialization } & $\begin{array}{l}\text { Combining } \\
\text { different usages } \\
\text { Location of }\end{array}$ & 36.7 & 48.3 & 15 & - & 4.07 & .989 \\
$\begin{array}{l}\text { usages } \\
\text { Use abandoned } \\
\text { spaces }\end{array}$ & 55 & 38.3 & 6.7 & - & 4.42 & .809 \\
$\begin{array}{l}\text { Combining } \\
\text { different usages } \\
\text { Use abandoned } \\
\text { spaces }\end{array}$ & 30 & 68.7 & 13 & - & 4.13 & .965 \\
\hline
\end{tabular}

Residents' information shows that $43.3 \%$ of respondent are male, and $56.7 \%$ are female, and $50 \%$ have master or Ph.D. degree (Table 2).

The respondents were asked to respond to the three types of questions: 1. The first type of question was related to their perception about the effect of combining 
different usage, location of usage and using abandoned spaces in socialization and the sense of security. The survey's questions were asked in two ways: their general opinion about these effects (Table 3) and the effects of these changes in their complex (Table 4).

According to the mean of each question, respondents believe that the location of usages has the highest effect and combining different usages has the least effect in security in general. But in their complex combining different usages has the highest effect in socialization.

Table 5: The Correlation between respondents' perception in general and their residential complex.

\begin{tabular}{llll|ll}
\hline & & & Socialization & \\
\cline { 2 - 6 } Correlations & $\begin{array}{l}\text { Security } \\
\text { different usages }\end{array}$ & $\begin{array}{l}\text { Location of } \\
\text { usages }\end{array}$ & $\begin{array}{l}\text { Use abandoned } \\
\text { spaces }\end{array}$ & $\begin{array}{l}\text { Combining } \\
\text { different } \\
\text { usages }\end{array}$ & $\begin{array}{l}\text { Use abandoned } \\
\text { spaces }\end{array}$ \\
\hline Pearson Correlation & .869 & .538 & .668 & .453 & .846 \\
Sig. (2-tailed) & .000 & .000 & .000 & .000 & .000 \\
\hline
\end{tabular}

The significance of results is 0.00 and less than 0.05 , so the results are acceptable. The questions about respondents' perception for understanding the effect of combining different usages in security in general and in their complex have the highest significance whit each other. Afterward the effects of using abandoned spaces in socialization use abandoned spaces in security, location of usages in security and combining different usages in socialization have the highest correlation in priority.

2. Another type of question is about the effect of usage's location in socialization and sense of security. For these questions, respondents had to choose between the centers, around and between of the residential buildings (we showed them in the picture). Respondents could also choose "no different" item to show their incuriosity. According to Table 6 , it is clear that the location of usages has almost equal effect in the sense of security and socialization.

Table 6: Respondents' perception about the effect of usage's location in socialization and the sense

\begin{tabular}{ccccc}
\hline $\begin{array}{c}\text { Frequency } \\
\text { for place }\end{array}$ & Center & Around & Between & No different \\
\hline & $\%$ & $\%$ & $\%$ & $\%$ \\
\hline Security & 40 & 18.3 & 28.3 & 13.3 \\
Socialization & 38.3 & 18.3 & 28.3 & 15 \\
\hline
\end{tabular}

3) In another type of question, respondents had to choose different kinds of usages that they have more sense of security or socialization in priority. They had to numbered different kind of usages such as residential building; commercial building, park, services building, educational building and religious building from 1-5 or 1-6 (depend on the number of items). 
Izadifar, A., et.al. / Journal of ASIAN Behavioural Studies (JABs), 3(9) Jul / Aug 2018 (p.149-158)

Table 7: Respondents' Priorities about the kind of usages that can increase their sense of security or socialization.

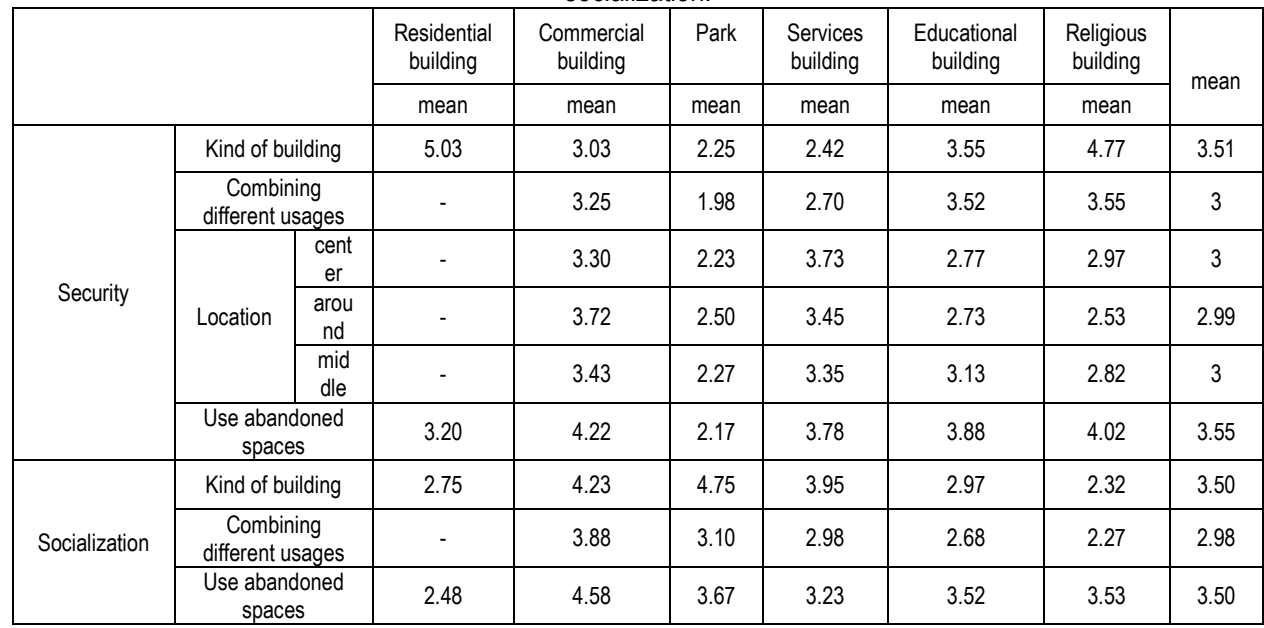

Respondents feel more secured next to residential and religious building and less next to the park, but their socialization is contrariwise different. People have the highest sense of security in the house next to a religious building and least in the house next to the park. But their socialization is more in commercial building and park and is less in a residential complex next to a religious building and for increasing security and socialization resident prefer to build commercial building in abandoned spaces in their residential complex. There is not any significant different in people's tendency about the kind of building that can increase the sense of security in different places.

\subsection{Conclusion}

The results of the research showed that support activity is one of the CPTED dimensions for increasing resident's security. The main conclusions are as follows:

- The results of this research showed that the best place for locating the usages is in the center of residential complexes. But it is better to put some usages with local users in the center and put another around the residential buildings. The place of usages is much more important that the kind of them. In general, building services and commercials buildings in a different part of a residential complex can easily increase the sense of security level.

- In Omid residential complex, parks and gyms are in the center, and commercial building is located around of residential buildings. For increasing security, it is better to combine commercial and services usages in park and locate them in the center of complexes. 
- Since there are a lot of abandoned spaces in Omid residential complex that are used as a park. The socialization in these spaces is high, but it could not increase the security of these spaces. The results showed that using abandoned spaces have more effect in increasing security than socialization. So it is recommended to build commercial, religious, educational, services and residential buildings in these spaces respectively.

- Residents feel more secure next to the residential building and less secure next to the park. In locating different usages next to residential building, religious building, educational building, commercial building and services building can increase the sense of security in a residential complex respectively.

\section{References}

Abdullah, A., Razak, A. N., Salleh, M. N. M \& Sakip, S. R. M. (2012). Validating Crime Prevention through Environmental Design Using Structural Equation Models. Procedia - Social and Behavioral Sciences, 36: 591 - 601.

Abdullah, A., Salleh, N. M. \& Sakip, S. R. M. (2012). Fear of Crime in Gated and Non-gated Residential Areas. Procedia - Social and Behavioral Sciences, 35: 63 - 69.

Abdul Mohit, M. \& Elsawahli, H. M. H. (2010). crime and housing in Malaysia: a case study of Taman Melati terrace housing in Kuala Lumpur, Asian Journal of Environment-Behaviour Studies 1(3): 25-36

Anuar, A. N. A., Bookhari, N. S. \& Aziz, A. N. (2012). The Effectiveness of Safe City Programme as Safety Basic in Tourism Industry: Case Study in Putrajaya. Procedia - Social and Behavioral Sciences, 42: 477 - 485.

Clarke, R.V. (ED.), (1997). Rational choice and Situational Crime Prevention, Ashgate. Siegel, Larry. J, (2001). Criminology, 7th edition, Wadworth.

Cozens, P., Hiller, D. and Prescott, G. (2001). Crime and the design residential Property-Exploring the Theoretical Background. Journal of Property Management, 19(2): 136-164.

Cozens, P. M, Hillier, D. and Thorn, M. (2008). Designing out crime in Western Australia: case study. property management 5(26): 309-295.

Crowe, T.D. (2000). Crime Prevention Through Environmental Design, stoneham,MA: Butterworth- Heinemann, PP.95-87

Jeffery, C.R. (1971). Crime Prevention through Environmental Design. Beverly Hills, CA: Sage Publications, 54-87.

Marzbali. H. M., Abdullah. A., Razak. A. N. \& Tilaki. M. J.M. (2012). The influence of crime prevention through environmental design on victimization and fear of crime. Journal of Environmental Psychology, 32: 79-88.

Mohit, A. M. \& Hannan, E. H. M. (2012). A Study of Crime Potentials in Taman Melati Terrace Housing in Kuala Lumpur: Issues and Challenges. Procedia - Social and Behavioral Sciences, 42: 271-283.

Newman, O. (1996). Creating defensible space, office of policy development and research. Washington DC: US Department of Housing and Urban Development.

Newman, O. (1972). Defensible space; crime prevention through urban design. New York: Macmillan. 
Petrella, Laura (2004). Urban Space and Security Policies: Between Inclusion and Privitilization. UN Habitat; WUF, Barcelona, Spain.

Pourjafar. R. M., Mahmodinejad. H., Rafieian. M \& Ansari. M.(2008). Promotion of Enviromental Security and Reduction of Urban Crimes with Emphasis on CPTED Approach. International Journal of Engineering of Iran University of Science and Technology 19(6): 73-82.

Sakip, S. R. M., Johari, N. \& Salleh, M. N. M. (2012b). The Relationship between Crime Prevention through Environmental Design and Fear of Crime. Procedia - Social and Behavioral Sciences 68: 628 - 636.

Sakip, S. R. M. \& Abdullah, A. (2010). Measuring Crime Prevention through Environmental Design in a Gated Residential Area: Pilot Survey. Procedia - Social and Behavioral Sciences 42: 340 - 349.

Shibata, S., Hanyu, K., Asakawa, T., Shimada, T. \& Omata, K. ( 2011). People's Crime Perception, and Attitude toward Community Crime Prevention Activities in Japan. Journal of ASIAN Behavioural Studies 1(2): 21-32

Shibata, S., Hanyub, K., Asakawac, T., Shimadad, T. \& Omatae, K. (2010). Community Activities to Protect Children from Crime, People's General Trust, and Attitude toward the Activities in Japan. Procedia - Social and Behavioral Sciences 38: 40-50

Soh, B. M. (2010). Crime and Urbanization: Revisited Malaysian Case. Procedia - Social and Behavioral Sciences 42: 291 - 299.

Villarreal, A. \& Silva, B. F. A. (2006). Social Cohesion, Criminal Victimization and Perceived Risk of Crime in Brazilian Neighborhoods. Social Forces, 84: 1725-1747.

Wekerle, G. R. \& Whitzman, C. (1995). Safe Cities: Guidelines for Planning, Designing and Management. Van Nostrand Reinhold, Canada. 